\title{
The costs of Utopia: Brasilia, Johannesburg, and Moscow
}

\author{
BERTAUD, Alain ${ }^{1}$ \\ ${ }^{1}$ New York University, New York, United States of America, abertaud@stern.nyu.edu
}

\begin{abstract}
Could utopian ideology influence cities' spatial structure to the point of overriding basic selforganizing principles that have been thought to be quasi universal?

In this paper, I define utopian ideology as a doctrine that is imposed by a central or local government and that aims at reaching a future state of optimum permanent equilibrium. Under my definition, the theory of free markets is the opposite of an utopian ideology because, first, free markets are spontaneously created by individuals and firms and cannot be imposed by governments, and second, because free markets imply constant adjustment toward an ever changing state of equilibrium which cannot be known in advance.

The main points developed in this paper are that (i) in some cases ideology could become the main determinant of urban shape, (ii) the spatial outcomes of opposite ideologies are often identical and (iii) Cities shaped by utopian ideologies impose a measurable cost affecting adversely the welfare of their inhabitants. While I concentrate on three extreme examples of ideologically shaped cities - Brasilia, Johannesburg and Moscow - I also show that milder cases of ideologies in cities like Curitiba (Parana, Brazil) and Portland (Oregon, USA) are having milder but not insignificant costs. I conclude that mild forms of utopian ideologies are still common in land use regulations, which in turn contribute to some inefficiencies and loss of welfare in many modern cities.
\end{abstract}

Key-Words: Utopian ideology, Free Market, Urban Space

\section{Resumo}

A ideologia utópica poderia influenciar a estrutura espacial das cidades a ponto de sobrepor-se aos princípios básicos de auto-organização, que se propunham praticamente universais?

Neste artigo, defino o conceito de ideologia utópica como uma doutrina imposta por um governo, seja local ou central, e que anseia em alcançar um estado futuro de equilíbrio permanente. Sob minha definição, a teoria do liberalismo econômico é o oposto da ideologia utópica, pois, primeiramente, mercados são criados espontaneamente por indivíduos ou firmas, não podendo ser impostos por governos; e segundo porque o liberalismo econômico implica em ajustes constantes em direção ao estado de equilíbrio impossível de ser previamente conhecido.

Os pontos principais desenvolvidos neste artigo são (i) em alguns casos a ideologia pode tornarse a maior determinante da forma urbana, (ii) o resultado espacial de ideologias opostas são constantemente idênticos e (iii) Cidades moldadas por princípios utópicos impõem um custo que afeta negativamente o bem-estar de seus habitantes. Enquanto me concentro em três exemplos extremos de cidades moldadas pela utopia - Brasília, Joanesburgo e Moscou - também apresento que casos de ideologias mais suaves em cidades como Curitiba (Paraná, Brasil) e Portland (Oregon, EUA) têm apresentado um custo menor, mas não insignificante. Concluo que formas suaves de ideologia utópica ainda são comuns para regulamentar o uso da terra, que contribui com ineficiências e perda do bem estar social em muitas cidades modernas.

Palavras-Chave: Ideologia utópica; Livre mercado; Espaço urbano 


\section{Theoretical framework}

I will use spatial indicators - density profiles, density gradients and dispersion index - to compare the spatial structure of 3 utopian cities with those of other cities that have been dominantly shaped by markets. However, these indicators require a central point usually associated with monocentric cities. It could be argued that some of the cities in the sample presented in this paper are polycentric and that therefore the indicators I have selected are inadequate to measure their shape. In the following section, I will show that indicators based on central points are relevant to both monocentric and polycentric cities.

\subsection{Monocentric and polycentric cities}

Traditionally, the monocentric city has been the model most widely used to analyze the spatial organization of cities. The works of Alonso (1964), Muth (1069), and Mills (1972) on density gradients in metropolitan areas are based on the hypothesis of a monocentric city. It has become obvious over the years that the structure of many cities departed from the mono- centric model and that many trip-generating activities were spread in clusters over a wide area outside the traditional CBD. Consequently, many have questioned whether the study of density gradients, which measures density variations from a central point located in the $\mathrm{CBD}$, has any relevance in cities where the $C B D$ is the destination of only a small fraction of metropolitan trips.

As they grow in size, the original monocentric structure of large metropolises tends with time to dissolve progressively into a polycentric structure. The CBD loose its primacy, and clusters of activities generating trips are spreading within the built-up area. Large cities are not born polycentric; they may evolve in that direction. Monocentric and polycentric cities are animals from the same specie observed at a different time during their evolutionary process. No city is ever $100 \%$ monocentric, and it is seldom $100 \%$ polycentric (i.e. with no discernable "downtown"). Some cities are dominantly monocentric, others dominantly polycentric and many are in between. Some circumstances tend to accelerate the mutation toward poly- centricity - historical business center with low level of amenities, high private car ownership, cheap land, flat topography, grid street design -; others tend to retard it - historical center with high level of amenities, rail based public transport, radial primary road network, difficult topography preventing communication between suburbs.

A large unified labor market is the raison d'être of large cities whether they are monocentric or polycentric. A large literature treats cities as labor markets like Ihlandfeldt, (1997) and the classic Goldner (1955). Prud'homme (1996) provides a convincing explanation for the growth of megacities in the last part of the twentieth century: Large cities become more productive than small cities when they can provide larger effective labor markets. Megacities' capacity to maintain a unified labor market is the true long run limit to their size. Market fragmentation due to management or infrastructure failure should therefore result initially in economic decay and eventually in a loss of population ${ }^{1}$. In this paper, I am considering the spatial structure of a city as the possible cause of labor markets consolidation or fragmentation. It is obvious that the fragmentation of labor markets might have many different other causes, for instance, rigidity of labor laws or racial or sex discrimination.

A monocentric city can maintain a unified labor market by providing the possibility of moving easily along radial roads or rails from the periphery to the center (see Figure 1 (a)). The shorter the trip to the CBD, the higher is the value of land. Densities, when market driven, tend to follow the price of land, hence the negative slope of the density gradient from the center to the periphery.

The growth of polycentric cities is also conditional on providing a unified labor market. Some urban planners often idealize polycentric cities by thinking that a self-sufficient community is

\footnotetext{
${ }^{1}$ I am certainly not implying here that the quality of infrastructure creates urban growth or that an infrastructure break down is the only reason why a city would shrink in size. Exogenous economic factors are of course determinant. But if infrastructure is not a sufficient reason to explain growth the lack of it may explain stagnation in spite of favorable exogenous economic conditions.
} 
likely to grow around each cluster of employment. According to them, a number of selfsufficient "urban villages" would then aggregate to form a large polycentric metropolis (Figure 1, (b)). In such a large city, trips would be very short; ideally, everybody could even walk or bicycle to work ${ }^{2}$. Nobody has ever observed this behavior in any large city. A metropolis constituted by self sufficient "urban villages" would contradict the only valid explanation for the existence and continuous growth of large metropolitan areas: the increasing returns obtained by larger integrated labor markets ${ }^{3}$. The urban village concept is the ultimate labor market fragmentation. Although there are many polycentric cities in the world, there is no known example of an aggregation of small selfsufficient communities. In spite of not being encountered in the real world, the utopian concept of a polycentric city as a cluster of urban villages persists in the mind of many planners. For instance, in some suburbs of Stockholm urban regulations allow developers to build new dwelling units only to the extent than they can prove that there is a corresponding number of jobs in the neighborhood. The satellite towns built around Seoul and Shanghai are another example of the urban village conceit.

In reality, a polycentric city functions very much in the same way as a monocentric city: jobs, wherever they are, attract people from all over the city. The pattern of trips is different, however. In a polycentric city each sub-center generate trips from all over the built- up area of the city (see Figure 1 (c)) Trips tend to show a wide dispersion of origin and destination, appearing almost random. Trips in a polycentric city will tend to be longer than in a monocentric city, ceteris paribus. However, for a given point, the shorter the trip to all potential destinations, the higher should be the value of land. A geometrically central location will provide trips of a shorter length to all other location in the city. Therefore, we should expect polycentric cities to also have a negatively sloped density gradient, not

\footnotetext{
${ }^{2}$ This is an extreme version of views expressed in, for example, by Cervero (1989).

${ }^{3}$ Many papers such as Carlino (1979) and Sveikauskas (1975) document these increasing return to size.
}

necessarily centered on the CBD but on the geometric center of gravity of the urbanized area. The slope of the gradient should be flatter, as the proximity to the center of gravity confers an accessibility advantage that is not as large as in a monocentric city. The existence of a flatter but negatively sloped density gradient in polycentric cities can be observed in cities that are obviously polycentric, like Los Angeles.

Density gradients, and other indicators linked to a central geometrical point, therefore constitute very useful tools to reveal and compare the spatial structure of cities, whether they are monocentric or not. In many cities, the center of gravity and the historical CBD coincide, in particular in cities with few topographical constraints. When in a polycentric city these two points do not coincide, the center of gravity should be selected instead of the CBD to calculate the density gradient. In most large cities, some trips are following the monocentric mode from a random point to a central point-while others are following the polycentric mode - from random point to random points (Figure 1 (d)). In this case on could select either the CBD or the center of gravity of the population as the reference point for density gradients.

Figure 1: Schematic representation of trips patterns whithin a metropolitan area

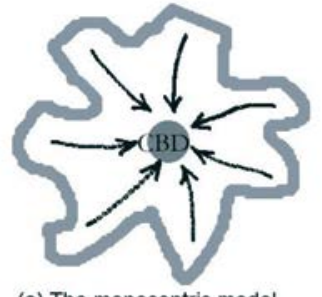

(a) The monocentric model

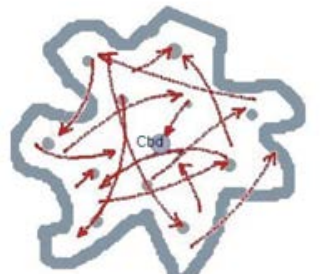

(c) The polycentric model: The random movement version weak links

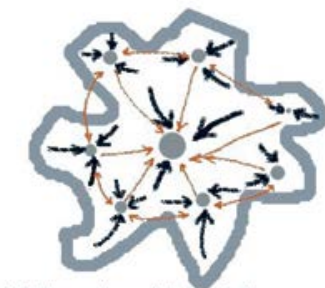
The urban village version

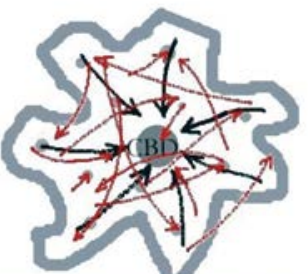

(d) The mono-polycentric model: Simulateous radial and random movements (b) The polycentric model:

In addition to the density gradient, I will use the "dispersion index " to compare the shape of 
various cities. The dispersion index was defined in Bertaud and Malpezzi (1999): "All else being equal, a city shape which decreases the distance between people's residence and the main place of work and consumption will be more favorable to the functioning of labor and consumer markets". For a given built-up area, the shorter the average distance per person to the main place of work or to the main commercial areas, the better would be the performance of the city shape.

The measure of the average distance per person to the CBD - in case of a monocentric city or to the center of gravity - in case of a polycentric city - provides a good indicator of dispersion for a given city over time or between alternative spatial options. However, to have a comparative measure of shape performance between cities, it is necessary to have a measure of dispersion independent of the area of the city. Everything else being equal, in a city with a small built-up area the distance per person to the center will be shorter than in a city with a larger built-up area. To correct for the area effect, the index of dispersion $\rho$, used in this paper is the ratio between the average distance per person to the $\mathrm{CBD}$, and the average distance to the center of gravity of a circle whose area would be equal to the built-up area:

$$
\rho=\frac{i^{\rho d_{i} w_{i}}}{\frac{2}{3} \sqrt{\frac{A}{\rho}}}
$$

Where $\rho$, is the index, $d$ is the distance of the ith tract from the CBD, weighted by the tract's share of the city population $\mathrm{w}_{\mathrm{i}}$; and $\mathrm{A}$ is the builtup area of the city.

The index of dispersion, $\rho$, is therefore independent from the area and from the density of a city; it reflects only the shape performance. It is therefore possible to use $\rho$ to compare cities of very different sizes and of very different densities. A city of area $X$ for which the average distance per person to the CBD is equal to the average distance to the center of a circle of area equal to $X$ would have an index of dispersion of 1. Of course, I am not arguing here that a circular city is somewhat optimal, merely that some cities will be more compact that this baseline (have a lower value of $\rho$ ) and some will be less compact (have a higher value of $\rho$ ).

\subsection{Self organizing principle vs. design}

The work of Alonso (1964), Muth (1069), and Mills (1972) made an important - but often overlooked - contribution to urban planning: it demonstrated that the spatial structure of many cities is generated by a self-organizing principle driven by economic forces. Self-organization might be a familiar concept for economists or for molecular-biologists but it is a startling and alarming one for urban planners and for people who think that nothing good could ever come from a blue print designed by an invisible hand.

I want to remind the reader that I am not talking here about urban design but about the spatial structure of cities. Haussmann did design street patterns in nineteen century Paris, so did L'Enfant in Washington. However, these "urbanists" only designed the boundaries between public and private use. They only allocated precise functions to public space: streets, avenues, parks, and public buildings. But they did not design the city in the sense that, with the exception of public monuments, they did not decide who was going to live where, they did not decide where offices and residential areas will be located and what should be the density in these areas. Market forces were left free to fill the bulk volumes allocated to private use.

Certainly, regulations and other public interests have affected the forms of Paris and Washington, but in the main, over the years, market forces have been bringing continuous change in land use and building density, while keeping intact the design of Haussman and L'Enfant. This demonstrates the differences between urban design and urban planning. The self-organizing principle applies to the filling of the private spaces, not to the design of the public space network constituted by streets, monuments, and large parks.

Which bring us to Utopian cities or cities whose spatial organization has been based on ideology rather than on the traditional combination of self-organizing process and urban design. How 
do we recognize an ideology-designed city? I propose the following definition: A spatial organization is based on ideology when the proponents of the arrangement think that the benefits brought by the ideology are obviously so high that it is blasphemous to even think of measuring its costs. In markets, costs and benefits are rarely measured explicitly at the aggregate level, but markets outcomes are, by definition, the result of the comparison of costs and benefits in many small private decisions.

Ideology has to be imposed from above, often by a central government, and therefore is seldom found in a democracy. In a city shaped by ideology, a planner decides on the activities and intensity of use that are allowed within the private spaces. The self-organizing principle generated by markets is not allowed to play a role.

One might argue that some modern zoning laws define entirely what is built in private space and therefore should tend to build utopian cities. This argument would be valid when a non-democratic government imposes the zoning laws and related land use regulations. A democratically elected government is usually obliged to be guided by real estate values when establishing zoning laws. The interaction of markets and the effects of local governance on land use regulations in democracies can be found in Epple (1988), Fischel (1995) and Hamilton (1978). Because of democratic pressures, zoning laws tend to evolve in time to reflect the changing economic circumstances of a city. In most cities, the density gradient implied by zoning laws is negatively sloped.

\subsection{Methodology}

To clarify the concept of utopia in planning, I propose to look at the case of 3 cities - Brasilia, Johannesburg and Moscow - whose spatial arrangement reflects ideology rather than any other practical or economic considerations. I will describe briefly in the next section how the ideology was translated into a spatial arrangement and what is this spatial arrangement, using the density gradient and the dispersion index described above.

The spatial structure of these cities will then be compared with the structure of 13 other mostly market driven cities, 2 of which - Curitiba and Portland (Oregon) - have a tendency toward ideology-guided design but being issued from a local democracy do not quite belong to the genre. In the market group, Berlin and Budapest have gone through 45 years of socialism but I found that the structure of these 2 cities were not unduly affected by this period in their history with no land markets. In Berlin, the existence of markets in the Western part of the city somewhat counteracted their absence in the Eastern part. In Budapest, the existence of a market driven large historical core, combined to a mellowing of the ideology when it came to housing ownership after the 1956 popular revolt also greatly reduced the effect and spatial scope of the central government ideology.

The market cities have not been randomly selected. They have been selected among a database of 50 cities that I have been assembling over the year while working on a book. These cities are:

$\begin{array}{lll}\text { 1. } & \text { Bangalore } & \text { (India) } \\ \text { 2. Bangkok } & \text { (Thailand) } \\ \text { 3. Berlin } & \text { (Germany) } \\ \text { 4. Budapest } & \text { (Hungary) } \\ \text { 5. Curitiba } & \text { (Brazil) } \\ \text { 6. Hyderabad } & \text { (India) } \\ \text { 7. Jakarta-Jabotabek } & \text { (Indonesia) } \\ \text { 8. London } & \text { (United Kingdom) } \\ \text { 9. Los Angeles } & \text { (USA) } \\ \text { 10. Marseille } & \text { (France) } \\ \text { 11. New York } & \text { (USA) } \\ \text { 12. Paris } & \text { (France) } \\ \text { 13. Portland } & \text { (USA) }\end{array}$

This limited selection of somewhat arbitrarily selected cities, certainly, does not allow performing any formal statistical test. The object here is more to compare cities qualitatively using a limited number of characteristics.

From my original data base, I selected cities that were located on flat ground without any serious topographical constraints, to match the 3 "ideological" cities that happen to be also located on flat ground. While the selection of the control group seems arbitrary, it has the great ad- 
vantage of having consistent data. Data consistency is one of the main problems in comparing the spatial structure of cities. There are many ways of calculating densities and establishing limits. The pattern of density of all these cities was established in the same manner. The set of polygons formed by census tracts were intersected by another set corresponding to the built-up area - defined as anything built or paved including small parks or left over space of less than 4 hectares, excluding airports, large parks, water bodies etc. Densities were then calculated for the built-up areas inside each census tract. To calculate gradients, the set of polygons formed by the built-up area inside census tracts were intersected with concentric circles at $1 \mathrm{~km}$ interval centered on the CBD. The built up area and the population within the intersect was used to calculate the density at successive $1 \mathrm{~km}$ intervals from the CBD. The resulting densities were then plotted on graphs where the distance from the center expressed in kilometers is on the $X$ axis, and densities, expressed in people per hectare are on the $Y$ axis.

\section{The three utopian cities: Brasilia, Johannesburg and Moscow}

Brasilia, Johannesburg and Moscow have been developed not only under very different ideologies but also different cultures, climates and economic systems. However, the spatial out- come of these ideologies is similar: All three have in common a positive density gradient and a large value for the dispersion index. Let us look first how these various ideologies did shape the spatial structure of each city.

\subsection{Brasilia}

Brasilia was built between 1956 and 1960 as the new capital of Brazil. The government of the time was socialist, promoting large State owned enterprises. Lucio Costa, the planner selected to design the city, was a Marxist and student of Le Cosrbusier. At the time Brasilia was built, it was thought that most cities were messy and that competent professionals should be put in charge of all aspects of urban life. Peter Hall (1988) quotes Le Corbusier on his views on the role of the planner: "The harmonious city must first be planned by experts who understand the science of urbanism... once their plans are formulated, they must be implemented without opposition". These views were obviously shared by both Costa and President Kubitschek who was president of Brazil at the time and took the initiative of building Brasilia during his 4 years terms. It was the time when the Soviet Union was considered an economic miracle and a model of efficiency.

Figure 2: Brasilia Density profile

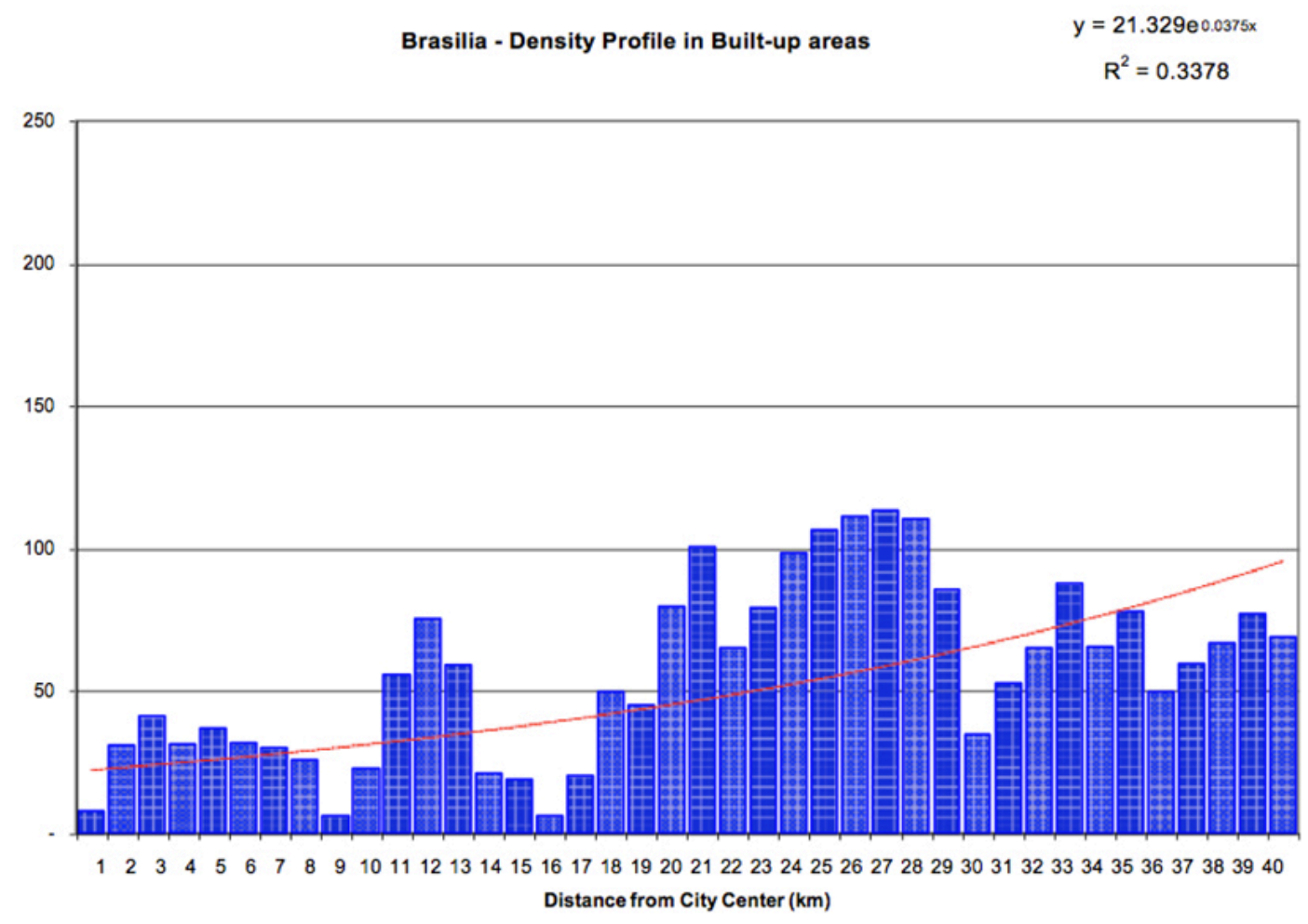


Source: "Order Without Design", Alain Bertaud, 2000

In Brasilia, highways are the core of the city and constitute monuments of civic pride. In the own words of Lucio Costa: "And, because the framework is so clearly defined, it is easy to build: two axes, two terraces, one platform, two broad highways running in one direction, one superhighway in the other." ${ }^{4}$ It may appear strange retrospectively but at the time many left leaning intellectuals such as the Le Corbusier and Costa thought that the private car was the mean of urban transportation of the future and a symbol of progressive modernity. This is in contrast with the views of left leaning thinkers today who tend to favor public transit over private automobiles. The entire city was entirely designed by the planner and a number of government appointed architects. No land values, rents or demand was considered. In this sense the main ideology that created Brasilia was a cult for design and a paternalistic attitude toward the masses. The land on which Brasilia was built was entirely acquired by the State and the construction of highways, government offices, shopping centers and housing was designed and built under direct government supervision without any market input. To this day, undeveloped land is still in government hands or under strict government control and no formal land market exist within the Federal District, although most already built buildings can be bought and sold on the market.

The city's lay out is in the shape of an airplane, with the government offices in the cockpit and the residential areas in the wings. In terms of employments, Brasilia is a dominantly monocentric city with government and government related jobs providing most employments.

The original design was completed by a number of satellite towns built at often more than $20 \mathrm{~km}$ from the core town in order not to spoil the general monumental effect. The total population is now 1.5 million people. In the absence of a real land market, nothing much has changed from the original concept, with the exception of a number of illegal upper middle class residential settlements located in areas zoned for agriculture.

\subsection{Johannesburg}

Figure 3: Johannesburg Density Profile.

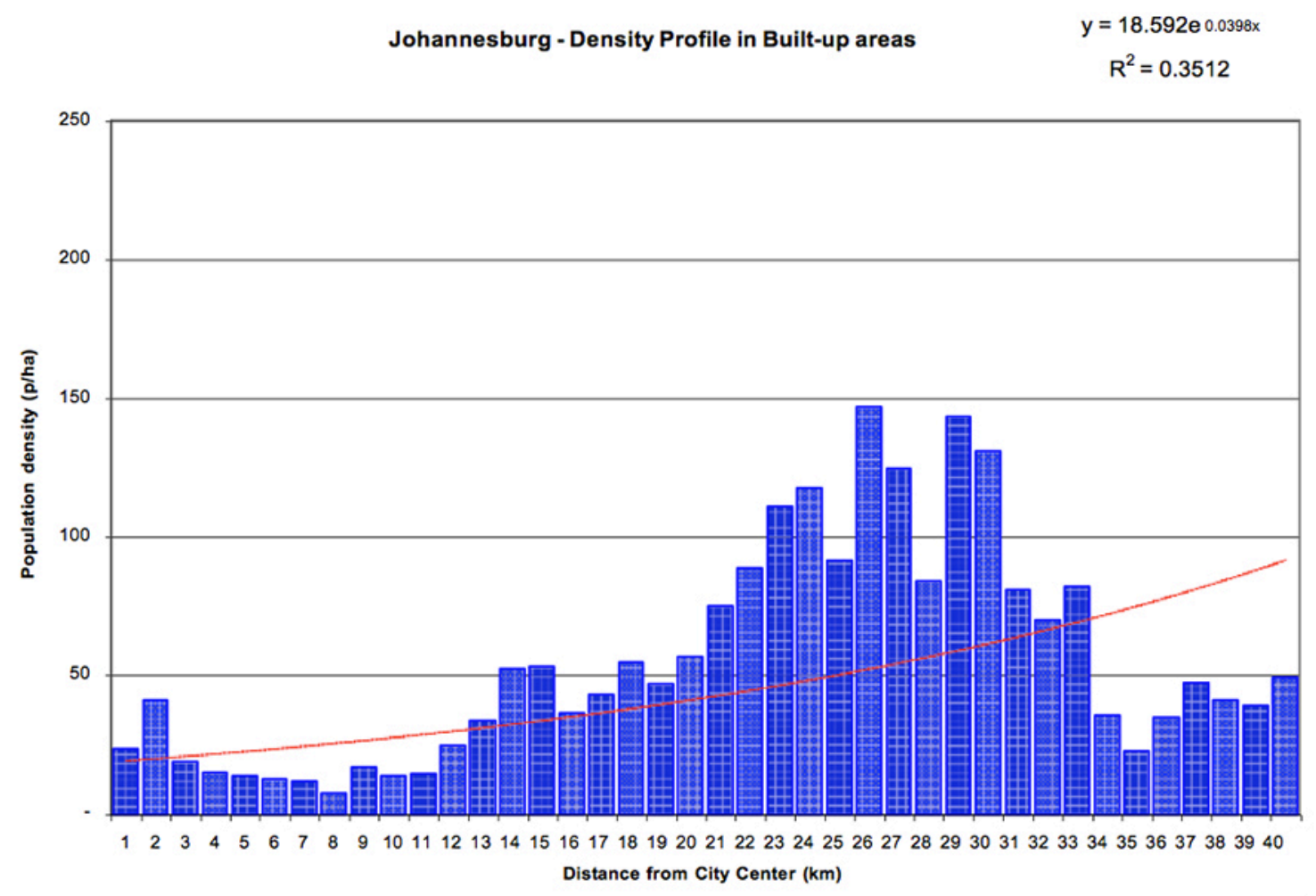

\footnotetext{
${ }^{4}$ Relatorio do plano piloto de Brasilia, Codeplan, dePHA Brasilia 1991.
} 
In Johannesburg densities rise with distance from the center, not by design as in Brasilia but as a side effect of apartheid policy.

Johannesburg during apartheid was a two tier city: in the first tier lived whites in residential neighborhoods heavily regulated but still driven by markets; the second tier consisted in a number of "black" and "colored" townships built within strict borders, that could not normally expand and where the large majority of people were living in rental housing owned by the state. Whites were living in low- density residential areas, which expanded in far away suburbs well served by a network of highways.

The spatial impact of the ideology is obvious in this case. The geographical separation of people by race was the main concept; one race living in houses built by the market, the other living under a socialist system with government tem of controlled urban migration enforced by internal passports existed in the former Soviet Union. Whites consumed a large amount of land per households and were located around the $\mathrm{CBD}$, while blacks consumed much less land in townships located in the periphery in areas specifically allocated to them. In terms of employment, Johannesburg is also a dominantly monocentric city. Blacks commuted to the CBD by trains, buses and collective taxis. Whites used private cars.

The area considered in this study is the Witwatersrand area, which included not only Johannesburg but also other suburban white municipalities and a number of peripheral black townships including Soweto and Orange farm.

\subsection{Moscow}

Figure 4: Moscow Density Profile.

Moscow - Density Profile in Built-up areas

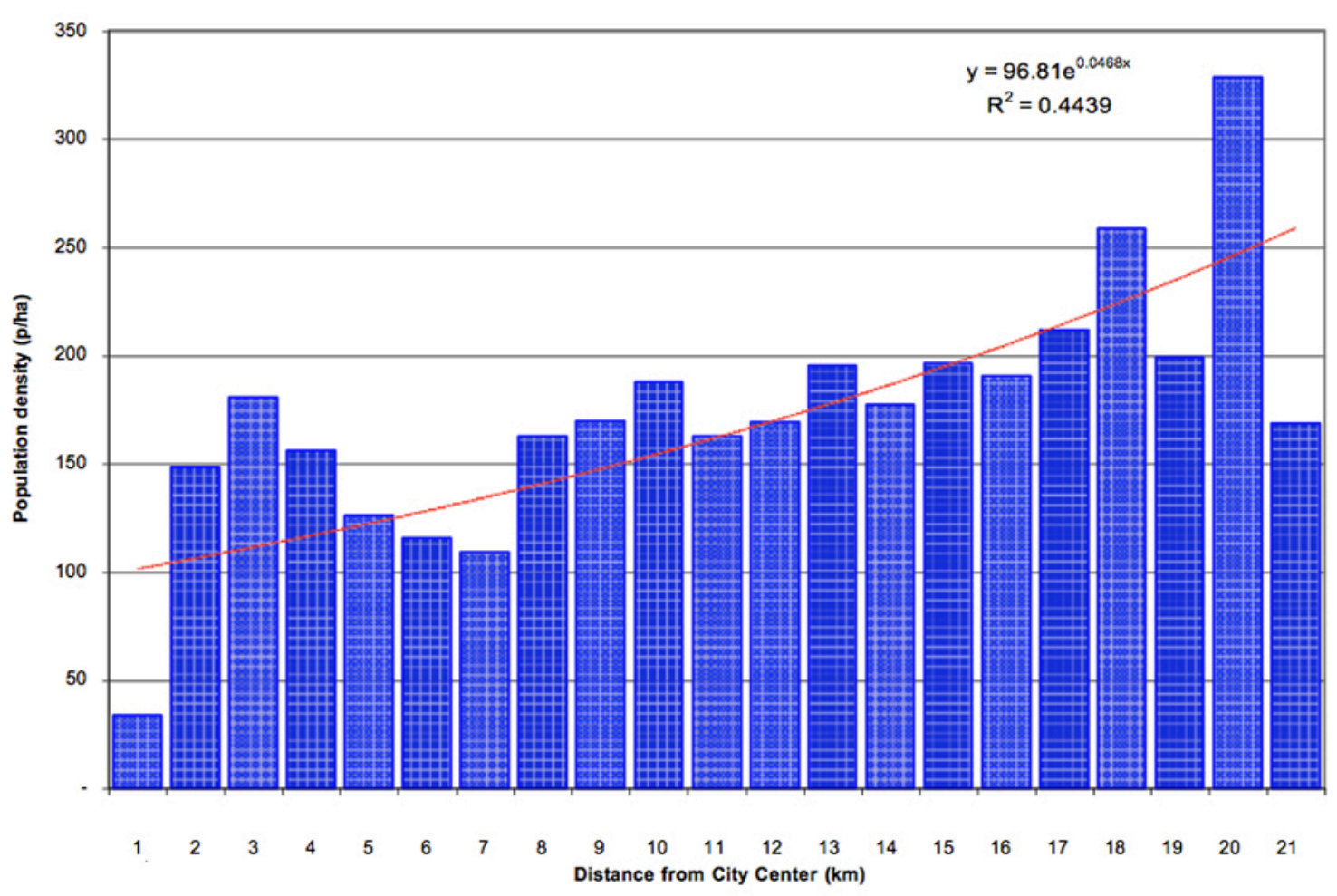

land ownership. The emigration of blacks from rural areas to townships was strictly controlled by a system of internal passport. The permit of residence in a black township could be obtained only after showing proof of formal employment and meeting migration quotas established by South Africans central planners. A similar sys-
Source: "Order Without Design", Alain Bertaud, 2000.

The positively sloped gradient is the consequence of the supply system of the Soviet regime where land had no value.

Moscow had a XIX century core whose structure was not very different from the one of Paris at 
the same period. The structure of the core was market driven. After the revolution of 1917, three concentric rings were built around the historical core; (i) during Stalin's time, a ring of heavy industries, symbols of the regime; (ii) during Khrushchev's time, a ring of 4 or 5 story walk up apartments; (iii) during Brezhnev's time, a high rise, high density residential belt using prefab panels technology. At the start of the October revolution, the density of the historical core must ture added a net cost to new construction not offset by the value of the land recovered. The supply driven system allowed State developers to built high-density housing at the periphery of the city without fear of rejection by the consumer.

\subsection{The lesser utopian cities: Curitiba and Portland}

Figure 5: Curitiba Density Profile.

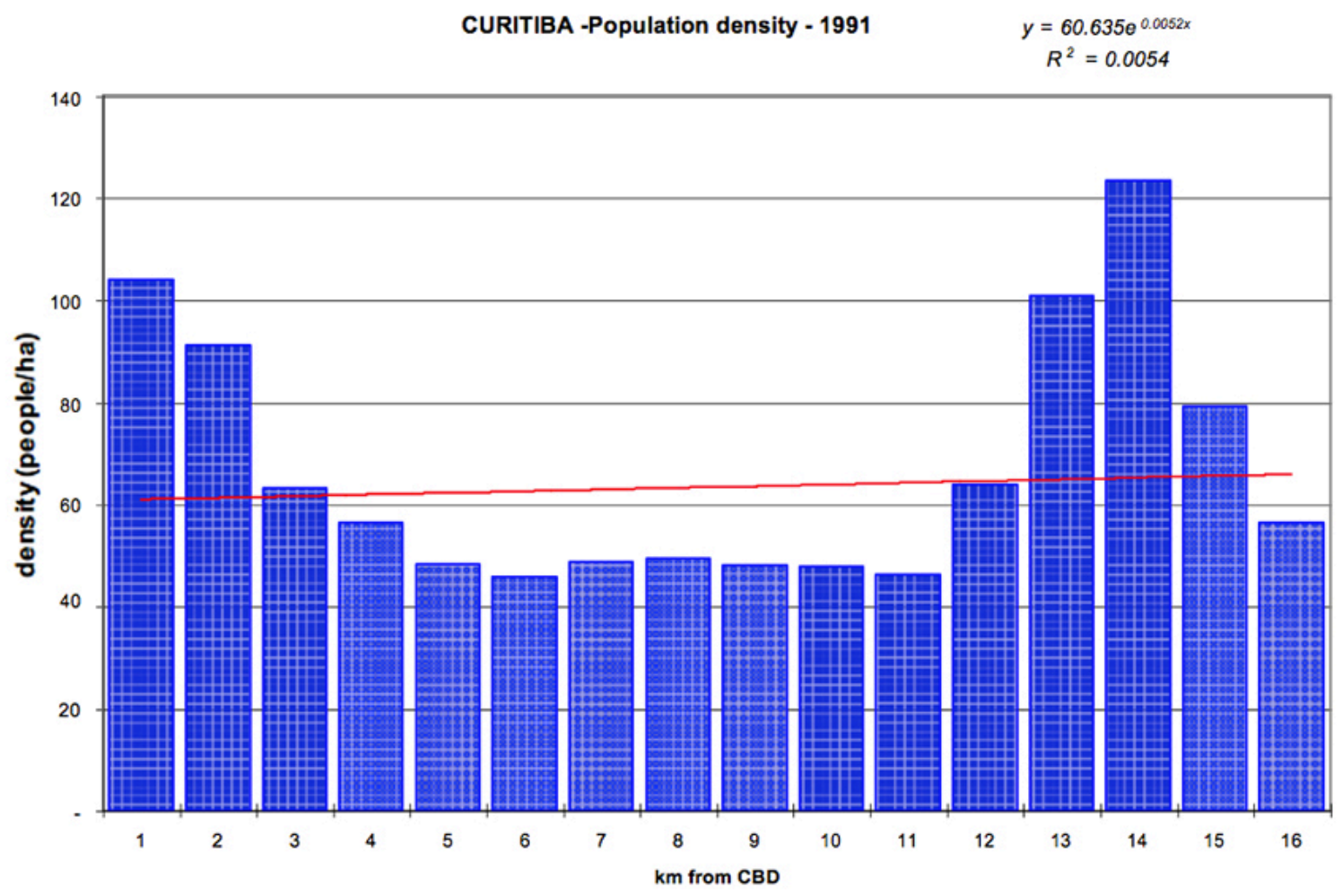

have been close to the density of Paris CBD or about 250 people per hectare.

Population density decreased after the revolution to the current $150 \mathrm{p} / \mathrm{ha}$ because of the need to accommodate the huge central bureaucracy that was managing the economy of the USSR.

Employment in Moscow is strongly monocentric, because of its network of radial primary roads and because of the elaborate metro lines converging toward the center. The city was built with a positive population density gradient, not as a deliberate design, but as a consequence of the fact that in the absence of property rights and of a resale market, it was impossible to recycle land once it had been built upon. Central planners did not recognize the value of land, therefore demolishing an existing obsolete struc-
Curitiba and Portland, from an ideological point of view, are only pale understudies of the 3 cities described above. However, through their land use regulations partially but deliberately contradicting markets these cities present a milder case of density gradient reversal.

Curitiba is a city that was designed by an architect. However, the architect was also the mayor, so the necessity of being reelected tempered his design utopia. In terms of employment, Curitiba is a monocentric city, but the recent construction of a ring road contributed to an increase in job dispersion.

Curitiba's zoning regulations do not approximately reflect supply and demand, as it is the case in most cities in market economies. Planners conceived Curitiba zoning as a design tool 
that would force the city's shape into a predesigned mold; the resulting shape was planned to be deliberately different from the one produced by the self organizing principle described by Alonso, Mills and Muth.

Market forces would normally increase population density around the CBD and decrease it progressively toward the suburbs. Curitiba zoning creates a high-density spine from the center ther increasing density in the periphery as shown on Figure 5. As usual, the practical outcome of a positive density gradient is longer trips for more people. In the case of Curitiba, low income households have longer trips while consuming very little land, instead of being able to make a trade-off between distance and land consumption.

Figure 6: Portland Density Profile.

PORTLAND - POPULATION DENSITY

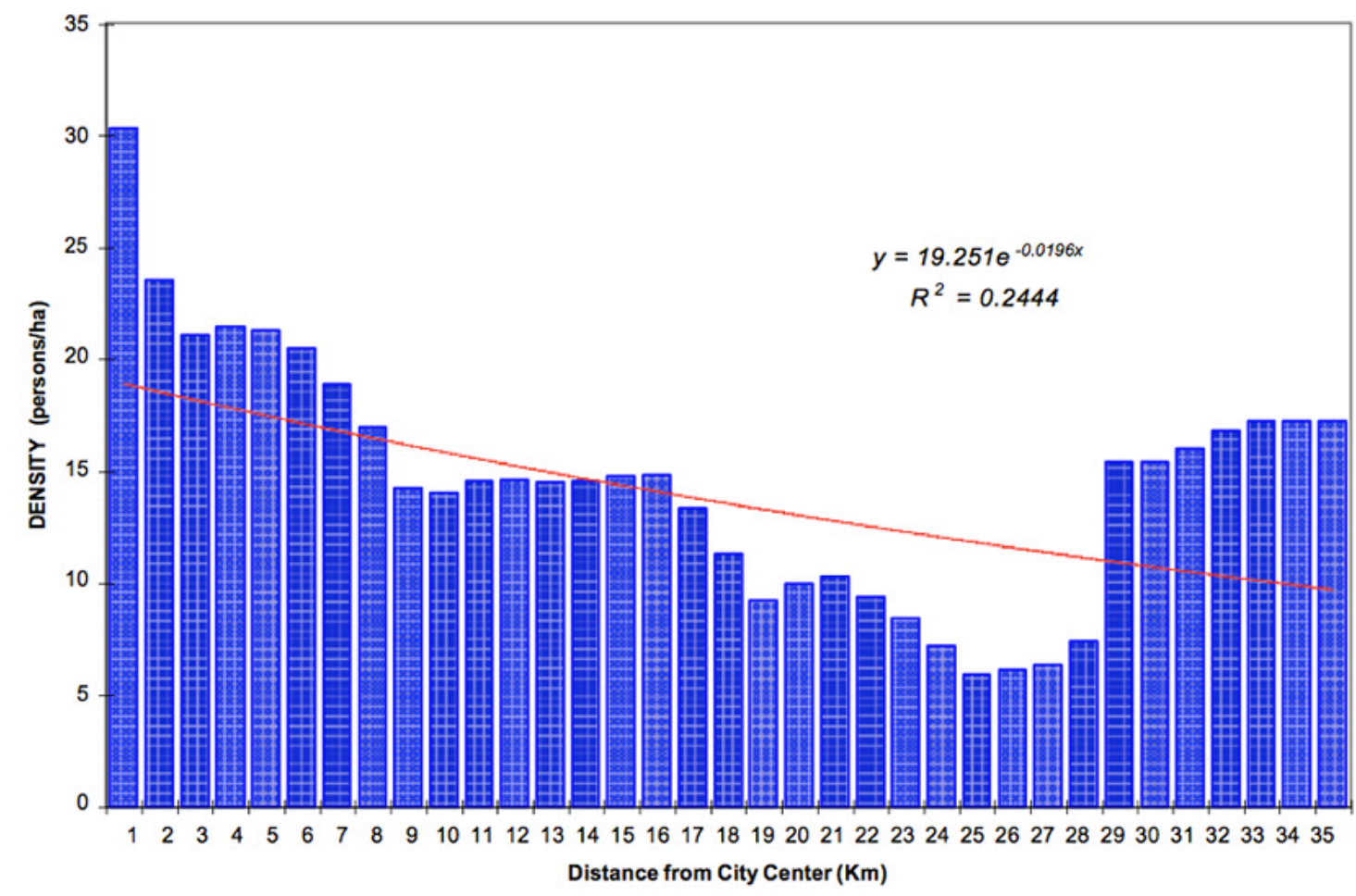

to the suburbs along a transport corridor. Areas close to the center but outside the spine are kept at a low density. Property owners in areas zoned for low density are given the possibility of trading development rights with developers who want to develop along the transport spine. The possibility of trading development rights in areas zoned for low density around the CBD is a clever way of avoiding political pressure from land owners who would otherwise have seen the value of their land greatly reduced by the low density zoning. Curitiba was built around a design idea that contradicts markets: building a city along a transport spine that will optimize the operation of buses at the expense of everything else. Low-income high density residential areas were built at the end of the transport spine, fur-
Portland's ideology is the environment. Improving the environment is certainly a worthy objective but it becomes an ideology when other factors are ignored, including the negative effects on the environment of trying to improve the environment. Portland developed the concept of an Urban Growth Boundary (UGB), which limits for 20 years the area within which the city may develop. The concept is interesting and would indeed promote compactness if there was real effective demand for higher density housing closer to the center and if current residents of neighborhood to be recycled were happy to sell their land for redevelopment at higher densities. Of course if these conditions existed, there would be no need for an UGB. Most neighborhoods resist any attempt at increasing signifi- 
cantly the current density and developers are uncertain about demand for higher density residential areas close to the center. As predicted, land prices are going up because of the supply constraint imposed by the UGB, developers respond by developing higher density housing in the vacant areas between the limits of the current built-up area and the UGB. This of course has a tendency to reverse the slope of the gradient. In terms of employment, Portland is a very polycentric city. In the long run, the higher density which will built-up on the vacant land along the UGB will increase the accessibility of suburban shopping malls at the expense of the relative accessibility of the CBD. This is not the outcome that the planners intended.

\section{How does the spatial structure of utopian cities compare to others?}

Table 1 shows the basic parameters corresponding to the 16 cities in the sample. The indicators we will compare are (i) the average density, (ii) the profile of density, (iii) the average distance per person to the CBD or center of gravity, (iv) the dispersion index, and (v) the density gradient. We should note the wide range of population, built-up area, and density in the sample. None of the 3 utopian cities, Brasilia, Johannesburg and Moscow are outliers for any of these parameters.

Table 1: Summary Data Table
The built-up area is measured for each metropolitan area by measuring the area of the polygons obtained by tracing the limits of the built-up area using land use maps, ortho-photos or satellite imagery. Undeveloped areas, forests, agricultural areas, parks larger than 4 hectares and airports are not included in the built-up areas. Industrial areas, railways yards and docks are included.

The average density is calculated by dividing the census population by the built-up area. It therefore corresponds to the inverse of the total amount of land consumed per person in each city.

The density gradient is calculated for each city by fitting an exponential curve over the profile of average density in the built-up measured within each successive 1 kilometer interval similar to the profiles shown in figure 2 to 6 .

\begin{tabular}{|c|c|c|c|c|c|c|c|}
\hline & Population & $\begin{array}{c}\text { Built-up } \\
\text { Area } \\
(\mathrm{km} 2)\end{array}$ & $\begin{array}{c}\text { av. } \\
\text { Density } \\
\text { (p/ha) }\end{array}$ & $\begin{array}{c}\text { av.distance } \\
\text { /person } \\
(\mathrm{km})\end{array}$ & $\begin{array}{c}\text { Dispersion } \\
\text { index }\end{array}$ & $\begin{array}{l}\text { Density } \\
\text { gradient }\end{array}$ & $\mathrm{R}^{2}$ \\
\hline Bangalore & $3,948,000$ & 191 & 207 & 5.1 & 1.00 & $(0.13)$ & 0.92 \\
\hline Bangkok & $7,628,000$ & 1,234 & 62 & 13.1 & 0.99 & $(0.06)$ & 0.86 \\
\hline Berlin & $4,212,000$ & 1,176 & 36 & 12.7 & 0.98 & $(0.04)$ & 0.62 \\
\hline Brasilia & $1,509,000$ & 272 & 55 & 20.2 & 3.26 & 0.04 & 0.33 \\
\hline Budapest & $1,937,000$ & 309 & 63 & 6.4 & 0.96 & $(0.11)$ & 0.76 \\
\hline Curitiba & $1,644,000$ & 287 & 57 & 7.7 & 1.20 & 0.01 & 0.01 \\
\hline Hyderabad & $3,044,000$ & 137 & 223 & 4.5 & 1.03 & $(0.11)$ & 0.88 \\
\hline Jakarta-Jabotabek & $14,909,000$ & 2,942 & 51 & 17.4 & 0.85 & $(0.04)$ & 0.79 \\
\hline Johannesburg & $5,415,000$ & 1,027 & 53 & 23.0 & 1.91 & 0.04 & 0.32 \\
\hline \begin{tabular}{|l} 
London \\
\end{tabular} & $6,626,000$ & 1,062 & 62 & 12.6 & 1.03 & $(0.02)$ & 0.53 \\
\hline Los Angeles & $9,317,000$ & 4,162 & 22 & 23.9 & 0.98 & $(0.03)$ & 0.94 \\
\hline Marseille & 800,000 & 151 & 53 & 4.3 & 0.92 & $(0.35)$ & 0.89 \\
\hline Moscow & $8,497,000$ & 503 & 169 & 10.6 & 1.25 & 0.05 & 0.50 \\
\hline New York Metro. & $10,753,000$ & 2,674 & 40 & 18.3 & 0.94 & $(0.05)$ & 0.83 \\
\hline Paris & $7,878,000$ & 893 & 88 & 10.0 & 0.89 & $(0.10)$ & 0.90 \\
\hline Portland & $1,230,000$ & 888 & 14 & 12.7 & 1.13 & $(0.02)$ & 0.24 \\
\hline
\end{tabular}


Figure 7: Comparative Average Population Density.

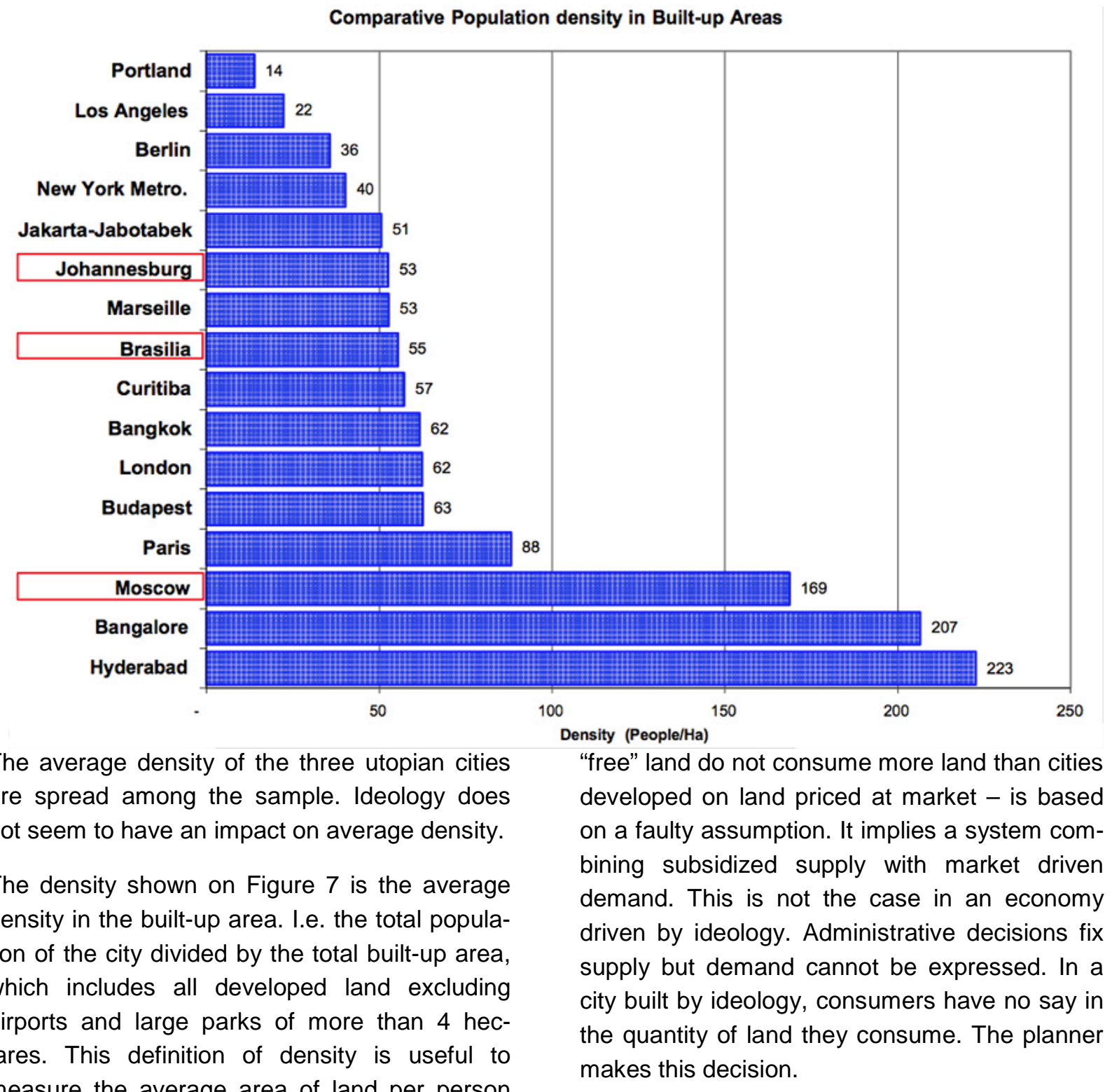

measure the average area of land per person used as input to produce the gross domestic product of a city.

One can see a wide spread of densities among all the cities, from a low 14 people per hectare in Portland, to a high 223 people per hectare in Hyderabad. There are no clear differences between the densities of cities developed under markets and those shaped by ideology. One would have expected that "ideology" cities developed without taking into account the price of land would have consumed more land - i.e. would have lower densities - than cities built with the cost constraint imposed by the market. This apparent paradox - cities developed on 


\subsection{Comparative density profile}

Figure 8: Comparative density Profile.

Population Density profile in the Built-up Area of Selected Cities
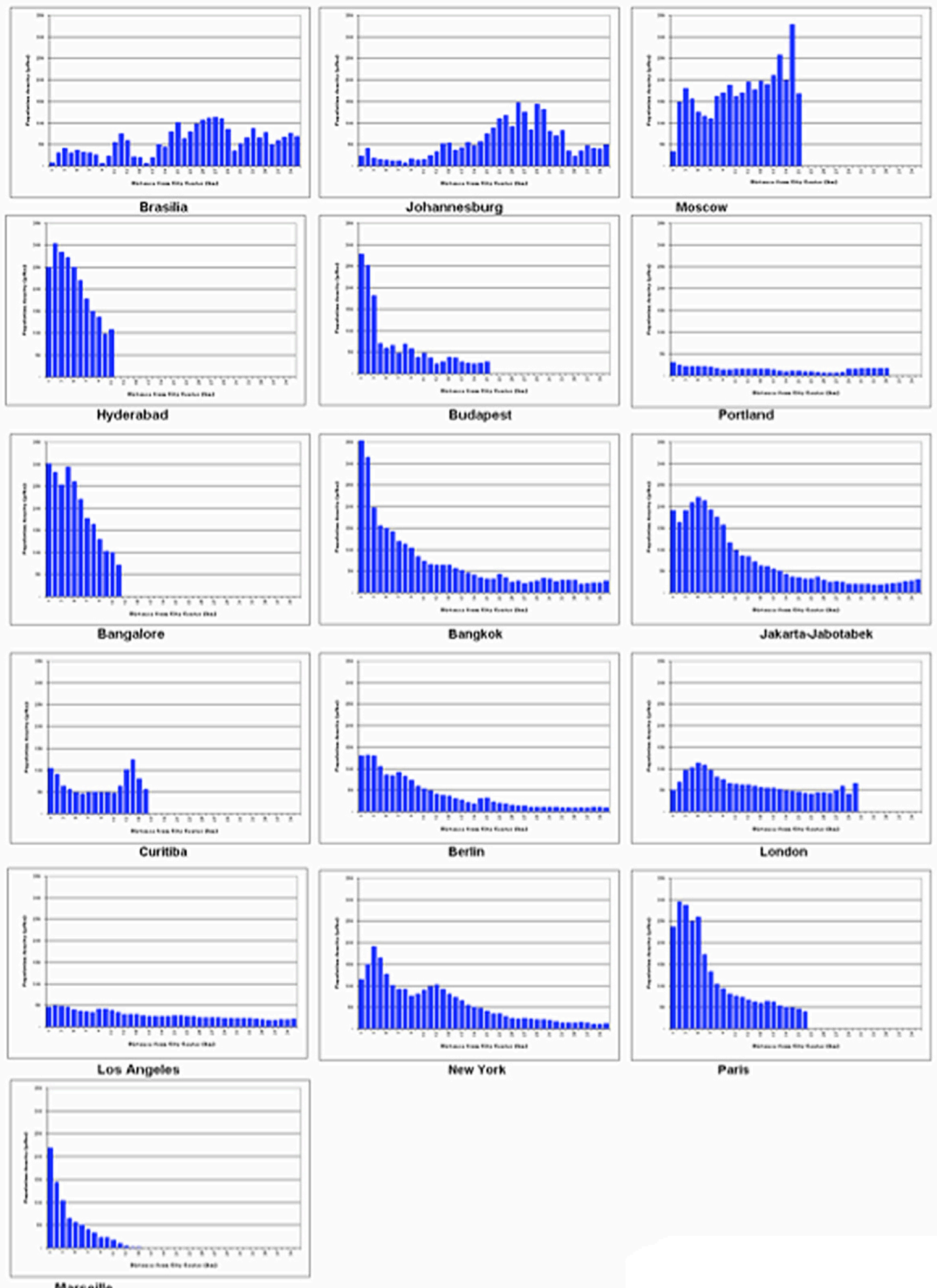

Marseille

Source: "Order Without Design", Alain Bertaud, 2000. 
The density profile of the 16 cities in the sample are represented at the same horizontal and vertical scale. The positive gradient of the utopian cities stand out among the other market driven cities.

The graph of Figure 8 shows the density profile of the 16 cities in the sample. The horizontal axis shows the distance from the CBD in kilometers ranging from 0 to 40 kilometers. The vertical to other cities that the profile appears flat. Refer to Figure 6 to see the density profile at a larger vertical scale.

\subsection{Average distance per person to the CBD}

Figure 9: Average distance per person to $\mathrm{CBD}$ related to the built-up area.

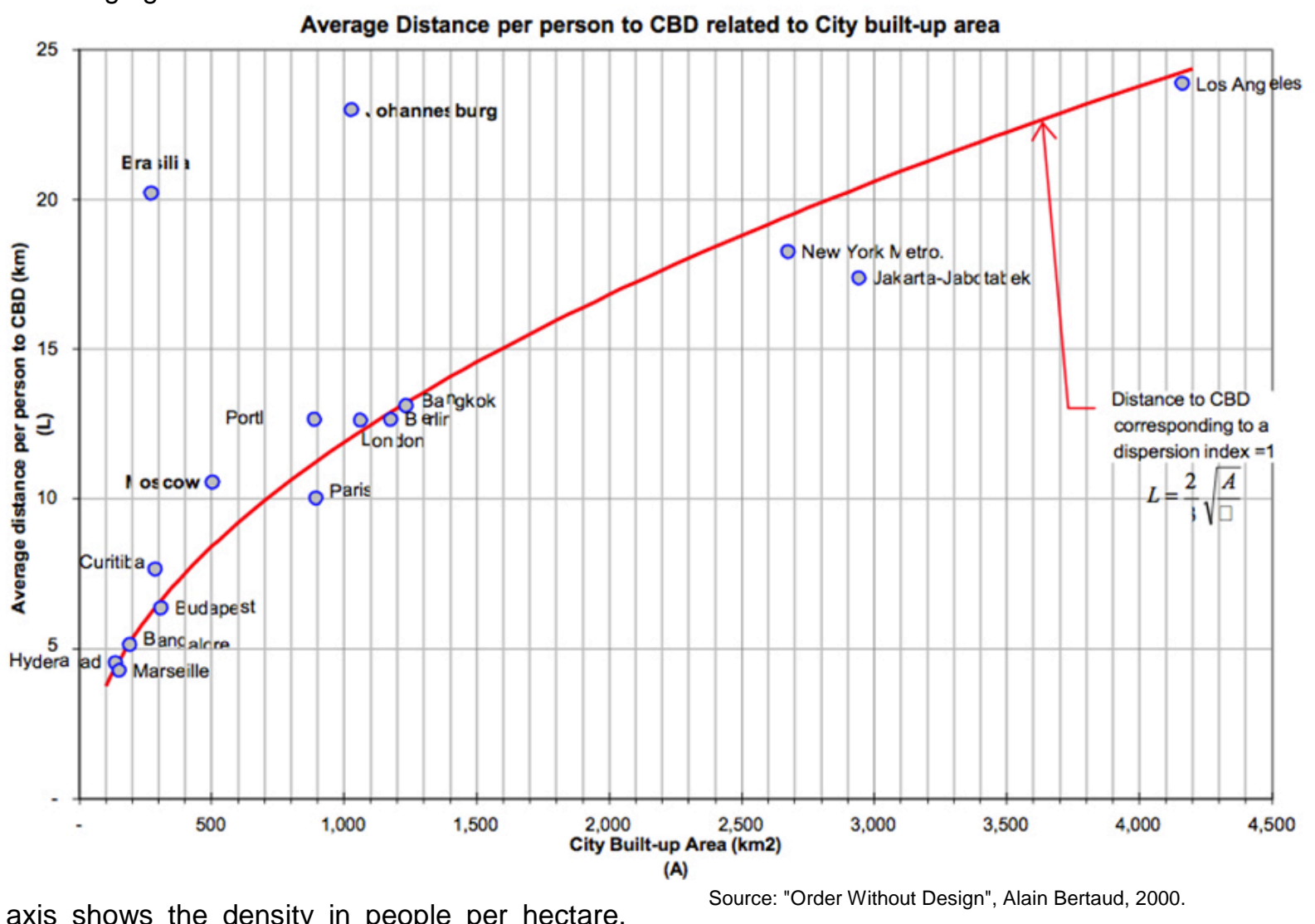

ranging from 0 to $350 \mathrm{p} / \mathrm{ha}$. The density profile of the three utopian cities is shown on the first row.

The three utopian cities are the only ones to show an erratic density profiles with densities increasing with distance from the center. By contrast, the 11 market cities (Bangalore to Paris) show certainly differences in densities in the center and the periphery but a remarkably similar profile with densities decreasing with distance from the center. We see here the effect of the self-organizing principle generated by markets, which is clearly independent from culture, climate, and income. The quasi- utopian cities of Portland and Curitiba are somewhat in between. Portland population density is so low compared
The graph of Figure 9 shows horizontally the built-up area in square kilometers as defined above and vertically the average distance per person in kilometers to the center of gravity or the CBD. The average distance per person to the center $d$ for a given built-up area is linked to the performance of the shape of the built-up area, in particular to the density gradient.

For a given shape, the average distance per person to the CBD increases with the size of the built-up area. The red line on the graph represents the variation of the average distance per person when the built-up area increases for a fictitious city that would be circular and that will have a uniform density. This standard circular and uniform density city becomes a benchmark 
for comparing the average distance per person for cities of different areas. It does not implies that a the shape of a circular city is good or bad, it is just a convenient measurement benchmark, similar to the water freezing point used to establish the 0o temperature in the Celsius system.

One could observe that, possibly by coincidence, most of the market cities are very close to the red line used as a benchmark, with a tendency to be below the line rather than above. This means that for most of the market cities in the sample, the average distance per person $d$ increases with the size of the city at about the same rate as it would increase in a circular city of homogenous density when its area increases.

Paris, New York and Jakarta are somewhat performing better than the rest of the cities with smaller value of $d$ for the size of their built-up area.

The outliers are Brasilia and Johannesburg and to a lesser extent Moscow, Curitiba and Portland. The difference in performance is staggering: Brasilia area is slightly smaller than Budapest but its $d$ value is more than 3 time larger! The value of $d$ in New York metropolitan area is only $10 \%$ smaller than the one of Brasilia while the built-up area of New York is nearly 10 time larger!

Johannesburg $d$ value is $80 \%$ larger than London's although it occupies an area that is slightly smaller than London. Moscow area is $75 \%$ smaller than Paris but its value for $d$ is $5 \%$ larger!

The calculation of $d$ allows us to have a measure of the diseconomy brought by a positively sloped density gradient. Moscow, because of its positive density gradient has an average distance $d$ per person to the center that is $32 \%$ longer than an equivalent city (i.e. same population, same area and of course same average density) that would have a negatively sloped gradient similar to, say, London or Marseille. While the variations in the value of $d$ represent a geometric concept, there is no doubt that there should be a strong correlation between $d$ and the average distance traveled everyday, whether the city is monocentric or polycentric.

Portland and Curitiba perform barely better than Moscow and significantly worse than the other cities, this is the effect of the "disturbed" density gradient of these 2 cities.

\subsection{Comparative dispersion index}

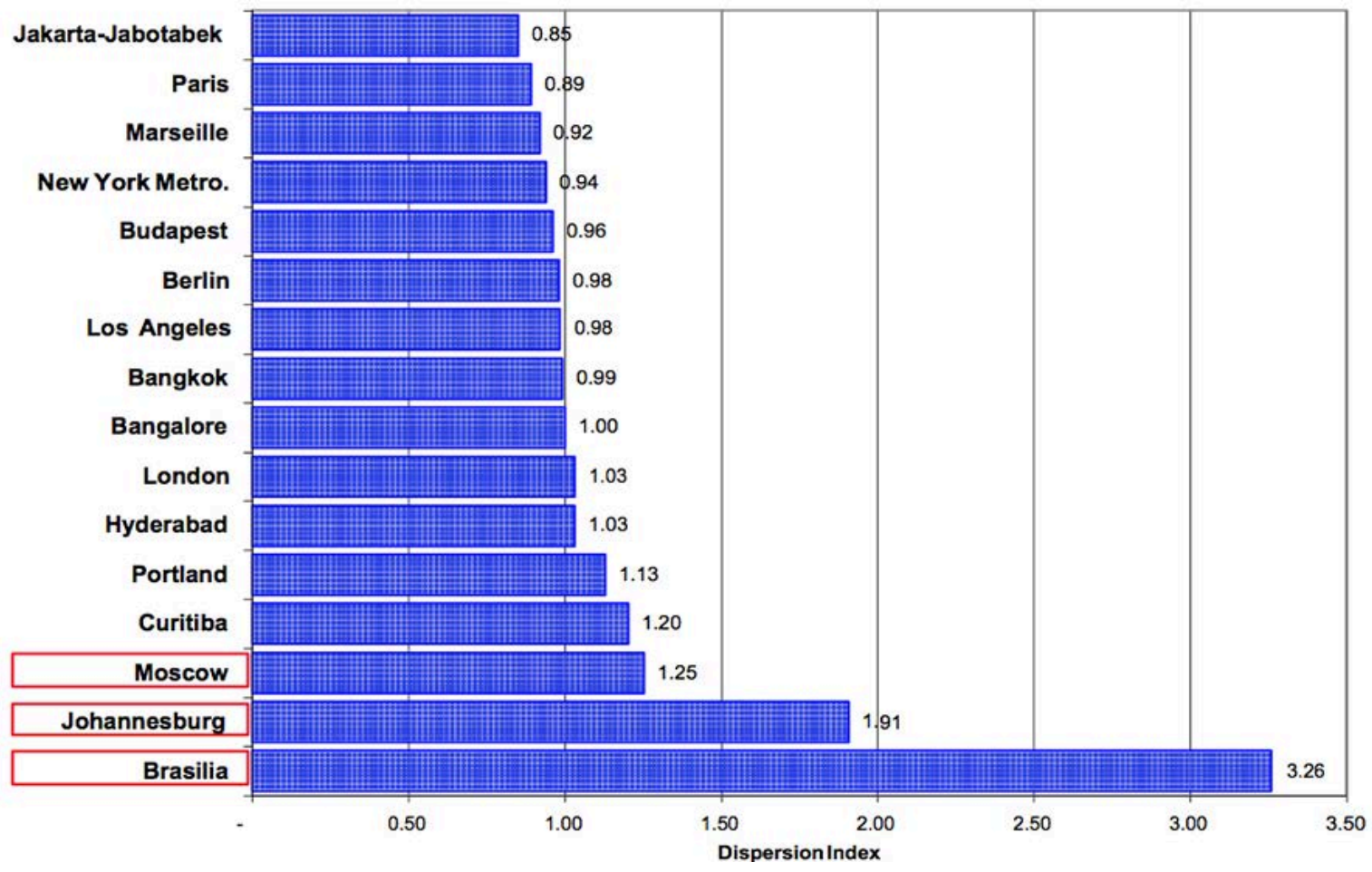


Figure 10: Comparative dispersion index.

Source: "Order Without Design", Alain Bertaud, 2000.

The dispersion index of the utopian cities is significantly higher than all the other cities in the sample. The "cult of design" appears to have a worse impact on dispersion than socialism. The ranking of Portland and Curitiba is consistent with their milder case of utopia. ties. The way densities are distributed in the built-up area is far more important than the value of the average density. Brasilia is twice as dense as Berlin but its population is much more dispersed and as a result trips must be much longer. Moscow, which is the densest European city in the sample, is also the most dispersed.

\subsection{Comparative Density gradient and $\mathrm{R}^{2}$}

Figure 11: Comparative density gradient and $\mathrm{R}^{2}$

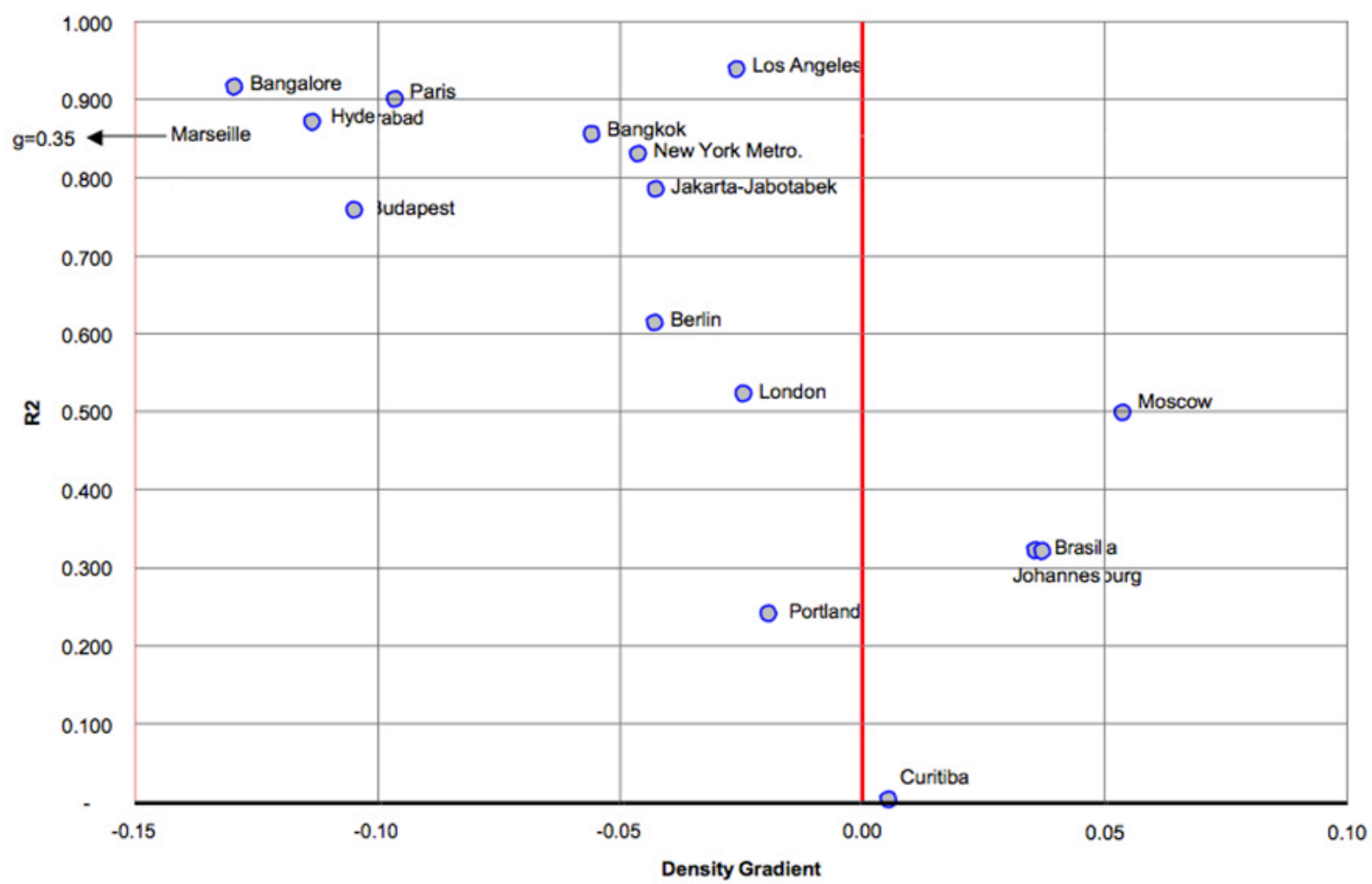

The dispersion index $\rho$ is a way of representing the shape performance of each city in a comparable way (see definition of $\rho$ in section A. (1)). Figure 10 shows the ranking of the 16 cities in the sample. We can see that market cities have different values for $\rho$ that are clustered between 0.82 for Jakarta to 1.03 for Hyderabad. The three utopian cities are clear outliers, with the milder utopian cities Portland and Curitiba performing significantly better than the utopian cities but not as well than the market cities.

We should note also that many urban commentators often associate higher densities with more compactness and shorter trips. We can see from Figure 9 and 10 that there is no necessary correlation between shortness of trips and densi-
As the market cities in the sample become more polycentric, the gradient becomes flatter but still negative consistent with the theory. The fit is also reasonably good except for London and Berlin. The gradient of Utopian cities is always a bad fit.

The graph of Figure 11 shows horizontally the density gradient and vertically R2 a measure of the goodness of fit of an exponential curve expected by the theory over the actual density profile. Most of the market cities in our sample have a acceptable fit (larger than 0.6) and as predicted by the theory (i) a negative gradient and (ii) the more polycentric a city, the flatter the gradient. Brasilia, Johannesburg, and Moscow have a positive gradient and a bad fit. 
Curitiba and Portland are outliers.

\section{Conclusions}

In our limited sample, cities that have nothing in common, except for a land market functioning reasonably well, have a similar spatial structure characterized by a negative density gradient. Cities that have nothing in common but are driven by ideology - whatever the ideology - tend to have a similar spatial structure characterized by a positive density gradient. Population dispersion is the price paid by households and firms living in cities where ideology is driving land use. Milder cases of ideological planning are producing milder cases of dispersion.

Dispersion increases the operational cost of a city by increasing the length of networks. It also increases the use of energy for transport and as a consequence it increases also air pollution. One should note that there is no direct inverse correlation between density and dispersion, contrary to what is generally thought. Moscow is one of the third densest city in our sample, but it is also the third most dispersed. Brasilia with more than twice the density of Los Angeles is three times more dispersed.

When planners try to improve urban design, i.e. when their intervention stays at the neighborhood level, the market can easily test their success or failure. For instance, the impact of a well designed, planner initiated, pedestrian street can be assessed by the increase or decrease of property values along the street, reflecting the positive or negative acceptability of the design by the general public. It is expected that by trials and errors planners could develop an experience, probably unique to each city, which allows them to improve the quality of the urban environment by designing and regulating the use of public space in close harmony with the demand driven use of private space. This coordination is always difficult if not impossible to accomplish by the private sector alone when relying on pure market mechanisms.

However, planners often attempt to apply at the metropolitan level the practice of designing by the proxy of regulations. Attempts to "design" or reshape an entire city through land regulations have unpredictable negative side effects, as the examples in this paper have shown. Measuring the economic costs and benefits of shaping a metropolitan area through regulations is a complex operation very different from measuring the performance of planners intervention in urban design. At the metropolitan level, positive or negative results appear only after a long time. Given the time resilience of urban shape, it is dangerous to engage in experiments that may prove to shape cities in an irreversible way. The diseconomies created by ideology in Brasilia, Johannesburg, and Moscow are going to persist long after these ideologies have been rejected.

Attempt to use land use regulations to shape a metropolitan area result in fact in an administrative allocation of land. A negative outcome is therefore hardly surprising. In the rest of the economy attempts to allocate inputs administratively have repeatedly resulted in sub- optimal results. There is no reason to think that an administrative allocation of land would produce any better results than an administrative allocation of, say, capital or of any commodity.

\section{References}

ALONSO, William. Location and land use. Harvard University Press, Massachusetts,1964.

BERTAUD, Alain. Cracow in the Twenty First century: Princes or Merchants? A city's structure under the conflicting influences of Land Markets, Zoning Regulations and a Socialist Past. ECSIN Working Paper \#8, The World Bank, 1999.

BERTAUD, Alain and BERTRAND Renaud. Socialist Cities Without land markets. Journal of urban Economics, 41,1997, pp137-51

BERTAUD, Alain and STEPHEN Malpezzi, The spatial distribution of population in 35 World Cities: the role of markets, planning and topography. The Center for urban land and economic research, The University of Wisconsin, Madison, 1999

BRUECKNER, Jan K. Urban sprawl: Lessons from Urban Economics. Papers on Urban Affairs 2001, Brookings-Wharton, Gale \& Pack editors, 2001. 
BRUECKNER, Jan K; THISSE, Jacques and ZENOU, Yves. Why is Central Paris Rich and Downtown Detroit Poor? An amenity based theory. European Economic Review 43 (1999) 91107.

CARLINO, Gerald A. Increasing Returns to Scale in Metropolitan Manufacturing. Journal of Regional Science, 19, 1979, pp. 343-51.

CERVERO, Robert. Jobs-Housing Balancing and Regional Mobility. American Planning Association Journal, 55, 1989, ppp. 136-50.

CLARK, Colin. Urban Population densities. Journal of the Royal Statistical Society, 114, 1951 pp. 375-86

EPPLE, Dennis; ROMER, Thomas and FILIMON, Radu. Community Development With Endogenous Land Use Controls. Journal of Public Economics, 35, 1988, pp. 133-62.

FISCHEL, William A. Regulatory Takings: Law, Economics and Politics. Harvard University Press, Massachusetts,1995.

GOLDNER, William. Spatial and Locational Aspects of Metropolitan Labour markets. American Economic Review, 45, 1955,pp.111-28

HALL, Peter, Cities of Tomorrow, Blackwell, Somerset, 1988, pp 210-219.

HAMILTON, Bruce W. Zoning and the Exercise of Monopoly Power. Journal of Urban Economics, 5, 1978, pp. 116-30.

IHLANDFELDT, Keith R. Information on the Spatial Distribution of Job Opportunities Within Metropolitan Areas. Journal of Urban Economics, 41, 1997, pp. 218-42.

MALPEZZI, Stephen and KUNG, Yeuh-Chuan. The flight to the suburbs, revisited: the intraurban distribution of population and the price of housing. January 1997

MILLS, Edwin. S. and SONG, Byong-Nak. Urbanization and Urban Problems. Harvard, 1979 Muth, Richard F. Cities and Housing. University of Chicago press, Chicago, 1969.

PRUD'HOMME, Remy, Managing Megacities,
Le courier du CNRS, no 82, 1996 pp 174-176 Sveikauskas, Leo. The Productivity of Cities. Quarterly Journal of Economics, 89, 1975, pp. 393-413. 